\title{
Geopolitical dimensions to build the Baku-Tbilisi-Ceyhan oil pipeline and the Nabucco gas pipeline to Western Europe
}

\author{
Dr. Mohamed Aziz Abdel-Hassan \\ Assistant Professor, College of Political Science / University of Baghdad \\ Received 06 Nov 2017, Accepted 07 Jan 2018, Available online 16 Jan 2018, Vol.6 (Jan/Feb 2018 issue)
}

\begin{abstract}
Baku-Tbilisi Ceyhan (BTC) pipeline carries oil from the Azeri-Chirag-Deepwater Gunashli (ACG) field and condensate from Shah Deniz across Azerbaijan, Georgia and Turkey. It links Sangachal terminal on the shores of the Caspian Sea to Ceyhan marine terminal on the Turkish Mediterranean coast. In addition, crude oil from Turkmenistan continues to be transported via the pipeline. Starting in October 2013, we have also resumed transportation of some volumes of Tengiz crude oil from Kazakhstan through the BTC pipeline. The pipeline that became operational in June 2006 was built by the Baku-Tbilisi-Ceyhan pipeline company (BTC CO) operated by BP. The pipeline buried along its entire length is $1768 \mathrm{~km}$ in total length: $443 \mathrm{~km}$ in Azerbaijan, $249 \mathrm{~km}$ in Georgia, and 1,076km in Turkey The Azerbaijan and Georgia sections of the pipeline are operated by BP on behalf of its shareholders in BTC Co. while the Turkish section is operated by BOTAS International Limited (BIL). The diameter of the pipeline is 42 inches throughout most of Azerbaijan and Turkey. In Georgia the pipeline diameter is 46 inches. The pipeline diameter reduces to 34-inches for the last downhill section to the Ceyhan Marine Terminal in Turkey. Throughput capacity-one million barrels per day from March 2006 to March 2009. Since March 2009 it has been expanded to 1.2 million barrels per day by using drag reducing agents (DRAs). The hypothesis of our research stems from the following questions Baku-Tbilisi-Ceyhan oil pipeline and Nabucco gas pipeline "to Western Europe: Is it a re-engineering of drawing lines of power in the Caucasus or is it a step that could contribute to obstructing energy corridors between East and West? The Caucasus Energy Department begins in the oil-and-gas-rich countries of the Caspian Sea, Azerbaijan, Turkmenistan and Kazakhstan. Azerbaijan, located to the west of the Caspian basin, is the source of any power lines emanating from the basin. In the north, Russia wants to be the only buyer from these sources, so that it can capture sales to Western markets. However, Azerbaijan has, to date, worked with the West and Turkey to build pipelines instead of working with Russia. "Turkey, which lies to the west, is shutting down the energy department as the last stop for pipelines. On the other hand, energy experts believe that the improvement of TurkishArmenian relations should not be at the expense of the East-West energy corridor, in other words, cooperation with regard to pipelines extending from Azerbaijan to Turkey. This corridor is a critical strategic tool for Washington to reduce the Western dependence on oil and gas from the Middle East. Oil exports through the Baku-Tbilisi-Ceyhan pipeline amounted to 14.9 million tons in the first half of this year, up 2.8 percent from the same period in 2015, according to a report by Reuters. Oil exports through the pipeline, which passes through Georgia and Turkey, rose 1.5 percent in 2015 to 28.84 million tonnes. Azerbaijan exports oil through the pipeline from the oil fields of Shiraj and Jonsheli, operated by British company BP. Crude is also exported through Russia through the Baku-Novorossiysk pipeline, through the Georgian territory by rail and through the Baku-Supsa pipeline. Kazakhstan and Turkmenistan are also exporting oil via the Baku-Tbilisi-Ceyhan pipeline. These rates are expected to rise during 2016/2017.
\end{abstract}

Keywords: The role of Turkey in the distribution of energy from the Middle East to Europe has increased Caspian Energy, Pipelines in Eurasia Energy Security Diplomacy Turkey's Energy Policy, Export Routes

The geo

\section{Introduction}

In the early 20th century, Ataturk established modern Turkey as a secular, European and Western state. He directed the state's resources towards social engineering

*Corresponding author's ORCID ID: 0000-0000-0000-0000 DOI: https://doi.org/10.14741/ijmcr.v6i01.10909 in a descending framework (starting with higher concepts and then going into details).

Today, Turkish President Erdogan used his power to form Turkey, as a Middle Eastern, conservative and politically Islamic country. To this end, Mr. Erdogan seeks to use Ataturk's methods in descending order (top to bottom).

$71 \mid$ Int. J. of Multidisciplinary and Current research, Vol.6 (Jan/Feb 2018) 
Under the AKP, Turkey has become a more politically and socially diverse country in the last decade, thanks to $\mathrm{Mr}$. Erdogan's economic growth. (1)

By adopting a three-pillar strategy as follows:

First: the adoption of Islamic economic - the "Islamisteconomic" orientation of the AKP's foreign policy to turn Turkey into a country with good relations and sometimes even more friendly relations with Iran, Russia, Syria, Sudan, Hamas, , Qatar and Saudi Arabia, which are similar to the relations they enjoy with the United States, the European Union and Israel. "

Secondly, Mr. Erdogan's understanding that the relationship between economic development and political stability is a very important complementarity, and that economic development and political stability cannot be achieved without attention to the social and economic aspect of the Turkish citizen.

Energy security is a growing concern not only for Turkey but also for many energy-import-dependent countries. This chapter examines how the role of energy security in Turkish foreign policy is constituted by material interests and ideational forces since March 2004(2).

The chapter is divided into three sections. The section 'Turkey's energy security and its asymmetric interdependence with gas suppliers' defines energyimport-dependency of Turkey and reviews the priorities in building pipeline projects since the start of the BakuTbilisi-Ceyhan oil pipeline, while the section 'Regional economic interdependence and Turkey's energy security: ideational forces and material interests' presents the material interests and ideational forces that constituted the role of energy security in Turkish foreign policy.

Finally, the section 'Shared material interests in booming exports to energy-rich neighbours' concludes with the examination of the case study to identify challenges and opportunities in enhancing the role of energy security in Turkish foreign policy (3).

Thirdly, the security of the Copenhagen School of thought is based on the Turkish national security issue. According to this theory, the government cancels a case from the political circle when it wants to deal with it as an exclusive concern for national security, allowing the state to take exceptional measures justified in Security threat status.

The Caucasus Energy Department begins in the oiland-gas-rich countries of the Caspian Sea, Azerbaijan, Turkmenistan and Kazakhstan. Azerbaijan, located to the west of the Caspian basin, is the source of any power lines emanating from the basin.

In the north, Russia wants to be the only buyer from these sources, so that it can capture sales to Western markets. However, Azerbaijan has, to date, wo ked with the West and Turkey to build pipelines instead of working with Russia. "Turkey, which lies to the last stop for pipelines. (4)
The United States joined the Caucasus Circle in the 1990s, with the support of the construction of the Baku-Tbilisi west, is shutting down the energy department as the Ceyhan oil pipeline from Azerbaijan to Turkey, thereby bypassing Russia.

This line was one of only two pipelines extending from the Caspian Sea to the west without passing through Russia.

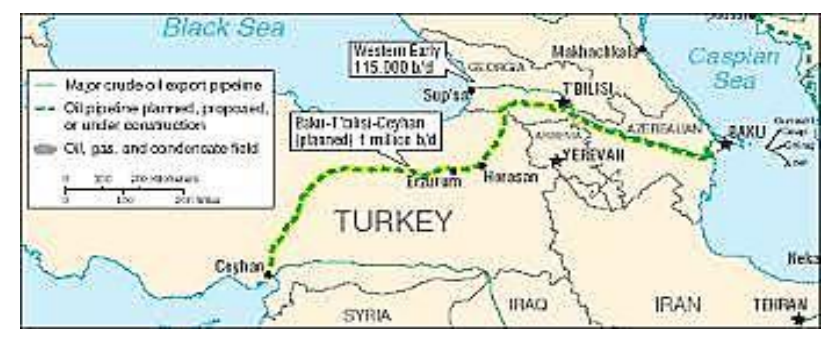

2. How do the United States, Turkey, Israel, Iran and Russia view this line?

For its part, Washington wants the Baku-Tbilisi-Ceyhan oil pipeline to flourish and projects for new pipelines, east to Kazakhstan and Turkmenistan or westward to Europe, including the extension of the Nabucco gas pipeline to estern Europe.

In this endeavor, Turkey is a very important transit country, but Azerbaijan remains the main country where the pipelines originate. The existence of Baku-TbilisiCeyhan and Nabucco oil pipelines cannot be without Azerbaijan; in other words, without the latter, the corridor between East and West will be merely a fictitious pipeline. (5)

Tehran has collided with Azerbaijan many times over the past two decades, and the nature of their relationship has not been the direct result of Azerbaijan's dealings with Israel. Israel's Azeri rapprochement is certainly one of the broader strategic challenges facing Baku (including repeated attempts by Iran and Russia to destabilize their attempts to regain control of the Caspian region), but Tehran is only part of these calculations.

Azerbaijan has good and independent strategic reasons for its cooperation with Israel and its weak relationship with Iran. In spite of Tehran's remarks, on the contrary, there are common regional trends linking Baku and Israel, and strong strategic cooperation with the United States, while Iran poses a strong security threat to the country.(6)

\section{Turkish-Armenian rapprochement and its impact on Turkey's relationship with Azerbaijan}

It can be said that Azerbaijan has had a conflict with Armenia since the early 1990s, owing to Armenia's occupation of Azeri territory, including the enclave of Nagorny Karabakh. Turkey has long supported the Muslim State of Azerbaijan - a Turkish-speaking country - against the Armenian occupation by keeping it on its border with Yerevan to force Armenia to withdraw. (7)

72 | Int. J. of Multidisciplinary and Current research, Vol.6 (Jan/Feb 2018) 
This position made relations between Turkey and Azerbaijan coherent in the 1990s, allowing the United States to work with both countries to build the BakuTbilisi-Ceyhan oil pipeline.

However, if Turkish-Armenian relations improve without Armenian guarantees to end the occupation, Azerbaijan will feel rejected by Turkey.

Analysts point out that Turkey will soon establish diplomatic relations with Armenia, open its border to trade with the country and launch a Turkish strategy towards Armenia as part of expanding the partnership on energy security in the Caspian basin and "partnership with Turkey on energy security." One way to diversify Turkish-American relations and shift focus from Middle East oil would be to join forces with Turkey to access Caspian energy fields and build pipelines for oil and gas pipelines, such as the long-anticipated Nabucco pipeline, to link Central Asia with Europe Via Turkey.(8)

Such a strategy would reduce the West's reliance on Middle Eastern oil and Europe's dependence on Russian energy, and would be a catalyst for the success of the talks between Turkey and the European Union.

In fact, in anticipation of the rapprochement between Turkey and Armenia, Azerbaijan has hinted that it wants to supply Moscow with gas and oil from its territory to express its friendship with Russia.

The trick lies in the normalization of Turkish-Armenian relations, with Turkey and Azerbaijan retaining their coordinated policies.(9)

\section{Will Azerbaijan-Armenia-Turkey, the backbone of Washington in the Caucasus Circle?}

Here the legitimate question arises:

Will the axis of Azerbaijan-Armenia-Turkey be the backbone of Washington in the Caucasus Circle, but this will only be possible if accompanied by the TurkishArmenian rapprochement currently under way, guaranteeing Armenia that it is ready to settle the Nagorno-Karabakh conflict with Azerbaijan.

Washington and Ankara should be organized into the Caucasus Circle to achieve this strategic goal.

Turkey and Armenia must move forward with their policy of rapprochement, and Washington must support this process. However, it would be unfortunate if the United States succeeded in winning Armenia while losing with Azerbaijan. The breakup of the Caucasus Energy Circle will bring US efforts in the Caucasus region to a dead end and lead to the renunciation of the whole region and its energy resources for the new owner's circle, Russia. (10)

On the other hand, energy experts believe that the improvement of Turkish-Armenian relations should not be at the expense of the East-West energy corridor, in other words, cooperation with regard to pipelines extending from Azerbaijan to Turkey. The corridor is a critical strategic tool for Washington to reduce Western dependence on oil and gas from the Middle East

\section{Turkey's Role in Caspian Energy Development}

Turkey aspires to become a key transit state for the transport of oil and gas from the Caspian region and the broader Middle East destined for European and world markets. At the heart of Ankara's energy policy is a fast growing economy with extremely high levels of dependence (11) on energy imports and a government intent on strengthening Turkey's position as a regional power. Over the past two decades, Turkey has experienced a dramatic surge in energy consumption, most of which has been satisfied by imports from Russia, Azerbaijan, and Iraq.

Predictable and close relations with these suppliers will be important for Turkey's ability to maintain its economic vitality az-ceyhan-mapln July 20142 billion barrels of oil delivered via the Baku-Tbilisi-Ceyhan (BTC) pipeline is planned to be shipped from the Mediterranean terminal Ceyhan. This forecast is based on the data of the tankers shipment in the Ceyhan port submitted by Botas International Limited (BIL) company, which is the operator of the Turkish part of the BTC oil pipeline. (12)

According to BIL, since beginning of oil shipment from BTC on June 2, 2006 till April 25, 2014 2,503 tankers have been shipped from Ceyhan. The volume of shipped oil totaled 1,924,000,000 barrels.

2500 tankers with oil from BTC has been shipped from Ceyhan on April 21, 2014.

Oil from the bloc of oil fields Azeri-Chirag-Guneshli (ACG) and condensate from the Shah Deniz gas condensate field in the Azerbaijani sector of the Caspian Sea is pumped via the BTC. Since signing of a new agreement in July 2010 Turkmenistan oil is also transported via the pipeline. Kazakhstan oil is pumped via BTC as well. (13)

BTC capacity is 1.2 million barrels a day. BTC Co shareholders include BP (30.1\%), SOCAR (25\%), Chevron (8.9\%), Statoil $(8.71 \%)$, TPAO (6.53\%), ENI (5\%), Total (5\%), Itochu $(3,4 \%)$, INPEX (2.5\%), ConocoPhillips (2.5\%) and Hess (2.36\%).

The Baku-Batumi oil pipeline was the first kerosene transportation line and crude oil from the oil fields near Baku, the capital of Azerbaijan, through the Caucasus, to the port city of Tommy, on the Black Sea coast of Georgia. When it was built in 1907, the pipeline was $833 \mathrm{~km}$ long, the longest of its kind in the world

Once completed, the Baku-Tbilisi-Ceyhan (BTC) pipeline will run 1,100 miles, from the Sangachal terminal near Baku, the capital of Azerbaijan, through Georgia and to the Turkish Mediterranean port of Ceyhan. (14)

The pipeline will carry $1 \mathrm{~m}$ barrels a day from the Caspian sea, which contains the world's third-largest oil and gas reserves. A total of $10 \mathrm{~m}$ barrels of crude oil is required to fill it. Estimates put reserves in the region at $33 \mathrm{bn}$ barrels, compared with around 715bn barrels in the Persian Gulf. Caspian production amounts to around $2 \mathrm{~m}$ barrels a day - roughly the same as Iraq.

73 | Int. J. of Multidisciplinary and Current research, Vol.6 (Jan/Feb 2018) 
The \$3.2bn (f1.74bn) pipeline, the largest private construction project in the world, is part of a $\$ 20 b n$ series of energy developments to produce and transport oil and gas from the landlocked Caspian. The British oil giant BP is the leading company in the consortium, which also includes the US firms Unocal and ConocoPhillips. (15)

The US favoured the pipeline on the grounds that it would lessen western dependence on Middle East oil and Russian pipelines, as well as well as avoiding Iran. While the pipeline crosses areas plagued by separatist conflicts, the countries involved hope it will bring economic benefits and enhance political stability.

Most Caspian oil exports currently go through Russian pipelines to the Black Sea port of Novorossiisk, where the oil is loaded onto tankers that squeeze through the very busy Bosporus. Russian officials tried to persuade Azerbaijan not to sign on to the project.

Azerbaijan is banking on it to raise its profile in the world and to bolster international support for Baku in its dispute with Armenia over the Nagorno-Karabakh enclave, which was taken over by ethnic Armenian separatists more than a decade ago. The conflict continues to simmer, undermining the region's security. Meanwhile, Georgia - which has troubled relations with Russia - sees the pipeline as a way of lessening its dependence on Russian energy supplies. (16)

Environmental and human rights groups have criticised the scheme. The Kurdish Human Rights Project and Friends of the Earth, amongst others, are particularly critical of Botas, the nationalised Turkish pipeline company, which is carrying out the construction work in Turkey.

Botas has been accused of offering far less compensation to landowners than promised, and NGOs say there have been cases of landowners being threatened for refusing to accept offers of compensation. They also allege that Ferhat Kaya, a human rights activist, was beaten up and tortured last year as a direct result of his work on cases of abuses related to land expropriation in Turkey. (17)

This pipeline is the second longest in the world (the longest is the Druzhba pipeline, from Russia to Central Europe) and the first to transfer oil from Asia to Europe, not via Russia. The pipeline was inaugurated in Jihan on May 28 ... The SCP (sometimes referred to as "Shah Deniz") is a natural gas pipeline connecting Baku, Tbilisi and Erzurum and passes through existing pipelines to the world market. The pipe carries gas from the gas field.

Oil exports through the Baku-Tbilisi-Ceyhan pipeline amounted to 14.9 million tons in the first half of this year, up 2.8 percent from the same period in 2015, according to a report by Reuters.

Oil exports through the pipeline, which passes through Georgia and Turkey, rose 1.5 percent in 2015 to 28.84 million tonnes. (18)

Azerbaijan exports oil through the pipeline from the oil fields of Shiraj and Jonsheli, operated by British company BP.
Crude is also exported through Russia through the BakuNovorossiysk pipeline, through the Georgian territory by rail and through the Baku-Supsa pipeline.

Kazakhstan and Turkmenistan are also exporting oil via the Baku-Tbilisi-Ceyhan pipeline. (19)

These rates are expected to rise during 2016/2017. It is noteworthy that a Greek company won the first contract for the construction of an oil pipeline linking Baku (Azerbaijan) to the port of Ceyhan (Turkey) via Tbilisi (Georgia) worth \$ 4.9 billion.

The US Energy Information Administration (EIA) has announced that Turkey is in a position to play an important role as a center for the transfer of oil and natural gas from the Middle East, Central Asia and Russia to Europe and the Atlantic.

The administration confirmed in its data published earlier in July that Turkey has been a major center for oil transportation, and is now gaining a greater position as a major center for natural gas.(20)

The Bosphorus and Dardanelles Straits are two main gates of crude oil from Russia and the Caspian Sea to international markets.

"Turkey is in a position to be a major hub for the transportation of natural gas," says the US Energy Department. "Most natural gas transmission lines carry gas into the country, however, as the growing demand for gas has not left enough for export."

Energy management attributed the rise in gas demand in Turkey to economic growth and rising energy demand, as the country worked to avoid a recession that hit most European countries. "Since 2010, Turkey has experienced one of the largest growth rates in energy demand among OECD countries," the administration notes.

Iran's gas pipeline, known as the Tabriz-Ankara pipeline, provides Turkey with 10 billion cubic meters of gas per year, according to data from the Turkish oil pipeline company BOTAŞ,

The Baku-Tbilisi-Erzurum pipeline, known as the South Caucasus pipeline, carries 6.6 billion cubic meters of gas annually to Turkey (21) export oil out of the region, the Russian route to Novorossiysk. For the first time, Russia's monopoly over oil export routes from the Caspian region has been broken, and with additional pipelines entering the scene in near future, this trend is likely to accelerate. (22)

Given the fact that the BTC line is operational and BTE is going to be fully operational in the second half of the 2006, Kazakhstan and Turkmenistan have robust alternative in order to diversify their chances to export their oil and gas. BTC has also decreased the cost of additional pipelines that would run parallel to the BTC line, such as the Baku-Tbilisi-Erzurum gas pipeline.

Together with the CPC pipeline, the BTC is the likely candidate to export the region's greatest oil reserves, such as Kazakhstan's Kashagan field.(23)

With ChevronTexaco's involvement to the project it can be argued that BTC has gained a kind of guarantee for a sustainable, direct, steady and reliable supply of crude 
oil (from Kazakh Tengiz and Kashagan fields) which will keep it operational well beyond its estimated lifetime and capacity

Baku-Tbilisi Ceyhan (BTC) pipeline carries oil from the Azeri-Chirag-Deepwater Gunashli (ACG) field and condensate from Shah Deniz across Azerbaijan, Georgia and Turkey. It links Sangachal terminal on the shores of the Caspian Sea to Ceyhan marine terminal on the Turkish Mediterranean coast. In addition, crude oil from Turkmenistan continues to be transported via the pipeline. Starting in October 2013, we have also resumed transportation of some volumes of Tengiz crude oil from Kazakhstan through the BTC pipeline.(24)

\section{Conclusion}

The pipeline that became operational in June 2006 was built by the Baku-Tbilisi-Ceyhan pipeline company (BTC Co) operated by BP.

The pipeline buried along its entire length is $1768 \mathrm{~km}$ in total length: $443 \mathrm{~km}$ in Azerbaijan, $249 \mathrm{~km}$ in Georgia, and $1,076 \mathrm{~km}$ in Turkey The Azerbaijan and Georgia sections of the pipeline are operated by BP on behalf of its shareholders in BTC Co. while the Turkish section is operated by BOTAS International Limited (BIL). (25)

The diameter of the pipeline is $\mathbf{4 2}$ inches throughout most of Azerbaijan and Turkey. In Georgia the pipeline diameter is 46 inches. The pipeline diameter reduces to 34-inches for the last downhill section to the Ceyhan Marine Terminal in Turkey.(26)

Throughput capacity - one million barrels per day from March 2006 to March 2009. Since March 2009 it has been expanded to 1.2 million barrels per day by using drag reducing agents (DRAs).

On 11 August 2014, BTC celebrated the loading of the 2 billionth barrel of oil at the Ceyhan terminal in Turkey.

The BTC pipeline passes through 13 districts in Azerbaijan: Garadagh, Absheron, Hajigabul, Agsu, Kurdamir, Ujar, Agdash, Yevlakh, Goranboy, Samukh, Shemkir, Tovuz, Agstafa; 7 in Georgia and 9 in Turkey.

In the first three quarters of 2017, BTC spent approximately $\$ 101$ million in operating expenditure and about $\$ 19$ million in capital expenditure.(27)

Since the $1,768 \mathrm{~km}$ BTC pipeline became operational in June 2006 till the end of September 2017 it carried a total of about 2.8 billion barrels (more than 374 million tonnes) of crude oil loaded on 3,674 tankers and sent to world markets.

During the first three quarters of 2017, BTC exported around 193 million barrels (about 26 million tonnes) of crude oil loaded on 249 tankers at Ceyhan.

The BTC pipeline currently carries mainly ACG crude oil and Shah Deniz condensate from Azerbaijan. In addition, other volumes of crude oil and condensate continue to be transported via BTC, including volumes from Turkmenistan and Kazakhstan. (28)

\section{References}

[1]. Sabit Bagirov, 'Azerbaijan Oil Oil: Glimpses of A Long History', Perceptions (Ankara), 1, 2, June-August 1996; Middle East Economic Digest (hereafter MEED), 30 September 1994, p. 42. 2 Bagirov, p. 35.

[2]. The Role of Energy Security in Turkish Foreign Policy (20042016 https:// link.springer.com/ chapter/10.1007/978-3319-50451-3 9

[3]. Implications of the baku-tbilisi-ceyhan main oil pipeline ... sam.gov.tr/wp-content/uploads/2012/02/TuncayBabali.pdf

[4]. The Baku-Tbilisi-Ceyhan Pipeline: Implications for Turkey, www.silkroadstudies.org/ component/jifile/download/...=/btc-6-pdf.html

[5]. Implications of the Baku-Tbilisi-Ceyhan Main Oil Pipeline Project (PDF ... https:// www.researchgate.net/.../ 280009625_Implications_of_the_Baku-Tbilisi-Ceyhan

[6]. The Case of Baku-Tbilisi-Ceyhan Oil Pipeline System: A Review Mustafa Balat www.tandfonline.com/doi/full/10.1080/009083190881517 ?scroll=top..true

[7]. Blue Black Sea: New Dimensions of History, Security, Strategy, ... https://books.google.iq/ books?isbn= 1443864757

[8]. Giray Saynur Bozkurt - 2014 - History 50Peter Symonds, "Oil Pipeline Completed: A Sign of Rising Great Power Rivalry in Central Asia," International Committee of the Fouth International, 2005, http://www.wsws.org/articles/2005/may2005/oilm31.shtml . ... 60Tuncay Babali, "Implications of the BakuTbilisi-Ceyhan Main Oil Pipeline Project,"

[9]. Eurasia's Shifting Geopolitical Tectonic Plates: Global Perspective,https://books.google.iq/books?isbn=14985255 12 Alexandros Petersen - 2017 - History Next Steps in Forging a Euroatlantic Strategy for the Wider Black Sea. Washington, DC: German Marshal Fund. Aydin, Mustafa (2005)

[10]. Regional Cooperation in the Black Sea and the Role of Institutions." Perceptions 10, no. 3: 57-84. Babali, Tuncay (2005). "Implications of the Baku-Tbilisi-Ceyhan Main Oil Pipeline Project.

[11]. The legal regime for the baku-tblisi-ceyhan (btc) oil pipeline projectwww.thecornerhouse.org.uk/.../ Implications\% 20of\% 20NCP\% 20Final\% 20Statement\% ...Mar 9, 2011

[12]. The project's legal regime consists of a number of agreements, which govern the construction, development and operation of the pipeline, and the social and environmental standards with which the project must comply.

[13]. Political and Investment Risk in the International Oil and Industry https://books.google.iq/books?isbn=14985461

[14]. Some 2,500 tankers carrying oil delivered via the BakuTbilisi-Ceyhan (BTC) pipeline have been shipped from Turkish marine terminal in Ceyhan, according to a message from BP, which operates the BTC.

[15]. Baku-Tbilisi-Ceyhan was blown up Not by Kurdish Bomb But by Russian Laptop" 18 December, 2014

[16].Q\&A: The Baku-Tbilisi-Ceyhan pipeline | World news | The Guardian https://www.theguardian.com , World , Azerbaijan

[17]. Turkey's Energy Market Reg- ulatory Authority (EMRA) announced in Janu- ary 2014 that Turkey would consume $46.5 \mathrm{bcm}$ in. 2014. Realization of Turkey's Energy 
Aspirations - Brookings Institution https:// www.brookings.edu/ wp content/uploads/.../ TurkeysEnergy-Aspirations.pdf

[18]. Promoting International Energy Security: Volume 2, Turkey and the ... https://www.rand.org /content/dam/rand/pubs /technical.../2012/RAND_TR1144z2.

[19]. In July, 20142 billion barrels of oil delivered to terminal via BTC ... caspianbarrel.org/.../2014/.../in-july-2014-2-billionbarrels-of-oil-delivered-to-termin...

[20].Turkey and Georgia: Zero-Problems? - The German Marshall Fund of ... www.gmfus.org/file/3054/download F +40 2131932 74. E BlackSeaTrust@gmfus.org. Summary: Over the past decade, relations between Turkey and. Georgia have flourished on the political, economic, and geostrategic ... The Baku-Tbilisi-Ceyhan Oil Pipeline. (BTC) is a step ... February 2013 and by President Mikheil Saakashvili in April. 2013. However ..

[21]. Gazprom Buys Armenia's Gas Distributor," International Oil Daily, January 17, 2014; "Russian Energy Giant Captures Armenian Market," Institute for War and Peace Reporting, January 24, 2014; "Gazprom increases share in Armenian gas distributor to $100 \%$," Oil and Gas Eurasia, January 17, 2014
[22]. Ministry of Foreign Affairs of Armenia. Protocol on the Establishment of Diplomatic Relations between the Republic of Armenia and the Turkish Republic and the Protocol on the Development of Mutual Relations Between the Republic of Armenia and the Turkish Republic, August 31, 2009, at http://www.armeniaforeignministry.com/ pr_09/20090831_protocol.pdf. See also The Turkish Weekly, August 31, 2009.

[23].U.S. Energy Department. Energy Information Administration. Azerbaijan: Country Analysis Brief, September 10, 2013.

[24]. Sedated Laciner, "Turkey's Pipeline Politics," The Journal of Turkish Weekly Online, International Strategic Research Organization, September 16, 2009.

[25].Speech to Plenary Session of Caspian Oil and Gas Conference, Ambassador Richard L. Morningstar, June 8, 2011; "Former U.S. Envoy [Matthew Bryza] Says Gas Project 'Impossible' without Azerbaijan," APA News Agency, March 28, 2012.

[26]. Eric Watkins, "New USGS Report Confirms Big Caspian Stakes," Oil \& Gas Journal, January 3, 2011.

[27]. Russian Gas Pipeline Could Doom Europe's Nabucco Plan," Reuters, May 28, 2013.

[28]. Cristian Campeanu, "How To Get Rid of Russian Gas Dependence After Nabucco Failure?" Libera, July 4, 2013. 